\title{
POSSIBLE SYNERGISTIC ANTI-CARCINOGENIC EFFECT OF MORINGA OLEIFERA AND CISPLATIN ON HUMAN SQUAMOUS CELL CARCINOMA
}

\author{
Dina M. Abdel Khalik* and Hala A. El-kammar**
}

\begin{abstract}
Introduction Moringa Oleifera (MO) is a cheap source of glucosinolates, falvonoids, among other components that may be used in the treatment of various illnesses including cancer. Cisplatin is a widely used anticancer chemotherapeutic agent. More than $90 \%$ of all oral cancers are squamous cell carcinoma (SCC). In spite of the advances in treatment modalities the survival rates have not improved.
\end{abstract}

Aim of the work: The aim of the present work was to assess the anticarcinogenic potentiality of MO extract alone and when used in conjunction with different doses of Cisplatin in treatment of human squamous cell carcinoma cell line.

Materials and methods: MO leaf extract, Cisplatin ${ }^{\circledR} 10 \mathrm{mg} / 10 \mathrm{ml} 1$ vial and HEp2 cells were used in the present study. In the present study, Cisplatin $20 \mathrm{mg}, 50 \mathrm{mg}$ and MO extract were used independently and in combination on HEp2 cell line. The expressions of caspase 9 and Beta catenin, and viability were assessed after 24 and 48 hours.

Results: Phase contrast microscopic results showed variations in morphology and number of cells between different subgroups. Highest Caspase 9 gene, least Beta catenin and least viability were noted when HEp2 cells were treated with Cisplatin $50 \mathrm{mg}$ and MO for 48 hours.

Conclusions: MO has an effective anticarcinogenic role on HEp2 cell line. The combined use of $\mathrm{MO}$ and Cisplatin is more effective than either of them alone, in a dose and duration dependant manner.

KEYWORDS: Moringa Oleifera, Cisplatin, Squamous cell carcinoma, Reactive oxygen species.

* Lecturer of Oral Biology, Faculty of Dentistry, Ain Shams University

** Lecturer of Oral Pathology, Faculty of Dentistry, Future University 


\section{INTRODUCTION}

Natural plants have drawn much attention for their pharmacological effects in the treatment and prevention of various diseases due to their biocompatibility, low toxicity, and potential biological activity $^{(1)}$. Moringa Oleifera (MO), also known as the 'drumstick tree,' is recognized as a nutritious and cheap source of phytochemicals. The plant has numerous medicinal applications and is used as a traditional medicine for the treatment of various illnesses such as skin diseases, respiratory distress, ear and dental infections, hypertension, diabetes, anemia, and most importantly in cancer ${ }^{(2,3)}$

Leaves of MO constitute a rich source of glucosinolates such as isothiocyanates (ITCs) and $\gamma$-tocopherol, falvonoids like quercetin ${ }^{(4)}$. MO leaf extracts have been shown to be both antioxidants and to act as anticancer agents through the induction of reactive oxygen species (ROS) and oxidative stress. Exactly how the same plant can behave in opposing ways is yet to be discovered ${ }^{(5)}$.

ROS acts as a doubled-edged sword in cancer. From one end, it causes DNA damage causing mutations that promote carcinogenesis. Moreover, ROS acts in signaling pathways, thus facilitating cell survival and cancer progression. On the other hand, excessive ROS promotes cytochrome $\mathrm{c}$ to be released into the cytoplasm and triggers programmed cell death. It has been proved recently that the anti- cancer roles of ROS depend greatly on its concentration $^{(6)}$. Cancer cells are more vulnerable to oxidative stress than healthy cells, several studies have proved that this may be attributed to 'Warburg effect'. The so-called Warburg effect states that tumors rely heavily on glycolysis to meet their metabolic demands. This process affects the homeostasis of ROS by affecting the concentration of reducing equivalents in the mitochondria, thus rendering cancer cells unable to cope with excessive $\operatorname{ROS}^{(7)}$.

Over production of ROS can induce apoptosis through caspases 9 activation ${ }^{(8)}$. Prolonged exposure to these ROS concentrations will result in P53 activation and subsequent p21 expression which will then result in a G1 cell cycle arrest ${ }^{(9)}$.

MO also contains ITCs which bring about epigenetic changes through modulation of DNA methylation, with a resulting activation or inactivation of several genes and signaling pathways ${ }^{(10)}$. Moreover, ITC was proven to inhibit proliferation of cancer cells and induce apoptosis via caspase 9 activation. ITC upregulates apoptotic signaling mediated by phosphorylation of p38 and JNK1/2 and at the same time, down regulating antiapoptotic signals mediated by ERK1/2 and AKT phosphorylation $^{(11)}$. Flavonoids are other bioactive components especially quercetin, which has been proven to down regulate AKT and upregulate caspases and p53 as well as to contribute to the production of $\operatorname{ROS}^{(12)}$.

Cisplatin (CisPt), cis-diammine dichloroplatinum is one of the most widely used and effective anticancer chemotherpeutics. CisPt induces interand intrastrand DNA adductions. Its action is mediated through the propagation of DNA damage recognition signals to downstream signaling pathways including ATR, p53, p73, and the mitogen-activated protein kinases (MAPK). Consequently, this results in cell cycle arrest and repair or apoptosis mediated by caspases including caspase $9^{(13)}$. In their work, Levina et al, 2004, postulated that p53 causes faster mobilization of Axin into the B catenin degradation complex thereby enhancing Beta catenin destruc$\operatorname{tion}^{(14)}$.

Nevertheless, the ability of Cispt to induce DNA damage does not seem to be sufficient to explain its high degree of effectiveness nor its effects on postmitotic normal tissues. Oxidative damage has been noted following exposure to CisPt in several tissues, suggesting a role for oxidative stress in the CisPtinduced cytoxicity ${ }^{(15)}$. CisPt rapidly builds up in the mitochondria and subsequently deteriorates the tricarboxylic acid cycle (TCA cycle) and glycolysis pathway. However, the precise mechanism of CisPtinduced metabolic toxicity remains obscure ${ }^{(16)}$. 
Dasari et al, 2014, ${ }^{(17)}$ stated that CisPt alone is not an effective drug in treating squamous cell carcinomas (SCC) and that it is better used in combination with other therapeutic agents ${ }^{(17)}$. Also, Shen et al., 2012 ${ }^{(18)}$, stated that in some instances CisPt resistance arises through a multifactorial mechanisms involving reduced drug uptake, increased drug inactivation, increased DNA damage repair, and inhibition of transmission of DNA damage signals to the apoptotic pathway ${ }^{(18)}$. Other mechanisms have been described like the progressive activation of survival pathways, especially the PI3-K/AKT signaling pathway $^{(19,20)}$.

A leading cause of death is oral cancer. More than $90 \%$ of all oral cancers are squamous cell carcinoma (SCC). Over the past three decades the 5 year survival rate of SCC patients has not improved, in spite of all the improvements in diagnostic techniques, and treatment modalities ${ }^{(21)}$.

Cancer is a multi-step process during which cells undergo pronounced metabolic and behavioral modifications. This leads them to proliferate in an exaggerated and untimely manner, to escape immune system surveillance, and eventually to invade distant tissues to form metastatic deposites ${ }^{(22)}$.

Typically, a series of mutations to Proto-oncogenes, tumor suppressor genes, DNA repair and genes that control apoptosis are required for a normal cell to change into a cancer cell ${ }^{(7)}$. Constitutive AKT activation is reported in many cancers. Activated AKT exerts its effects on a multitude of substrates that ultimately orchestrate the diverse cellular roles of AKT, including cell survival, growth, proliferation, angiogenesis, metabolism and migration. ${ }^{(19,20)}$.

It was found that AKT protein was down-regulated during apoptosis ${ }^{(23)}$. In return, AKT inhibits cell death by preventing cytochrome $\mathrm{c}$ release from mitochondria ${ }^{(24)}$ and eventual caspase 9 activation $^{(25)}$.

AKT phosphorylates Beta catenin which results in the latter's translocation to the nucleus, this sequence of events leads to cell cycle progression directly, and indirectly through loss of contact inhibition.
Added to the fact that, nuclear translocation of Beta catenin is considered to be a step in the dreaded epithelial mesenchymal transition (EMT) of cancer cells, where cells start to acquire morphological and behavioral patterns that are consistent with those of mesenchymal cells ${ }^{(26)}$.

The multifunctional protein Beta catenin creates a link between the cadherin and actin cytoskeleton. It also has a central role in transcriptional regulation in the Wnt signaling pathway. It interacts with transcriptional activators, thus modifying target genes like c-MYC2 and cyclin D1. This results in increased proliferation, invasion and cellular transformation. It has been estimated that approximately $10 \%$ of all tissue samples sequenced from all cancers display mutations in the CTNNB1 gene. Increased nuclear Beta catenin levels have also been noted in basal cell carcinoma (BCC), $\mathrm{SCC}^{(27,28)}$. Mutations of Beta catenin at and surrounding these serine and threonine residues are frequently found in cancers, generating mutant beta catenin that escapes phosphorylation and degradation ${ }^{(29)}$.

Under normal physiologic conditions, cytoplasmic Beta catenin is degraded by a destruction complex comprising APC, axin, glycogen synthase kinase $3 \beta$ (GSK3 $\beta$ ) and casein kinase ${ }^{(30-32)}$. It has also been reported that Beta catenin can be cleaved by protease including caspases ${ }^{(33)}$.

Levels of cytoplasmic Beta catenin are dynamically coordinated during the cell cycle, growing during $\mathrm{S}$, accumulating at the $\mathrm{G} 2 / \mathrm{M}$ and then sharply falling as the cells proceed into a new G1 phase. Simultaneously, elevated cytoplasmic and nuclear sublocalization of Beta catenin takes place during S and G2 phases. Accumulation of Beta catenin in epithelial cells causes a G2 arrest and leads to apoptosis, this supports the need for a tight control on beta catenin levels to guarantee correct progression of cells through cell cycle ${ }^{(34)}$.

Genomic abnormalities result in a delay in cell cycle progression along with the DNA repair response. Apoptosis takes place only when a cell sustains severe damage so much so that it cannot be repaired ${ }^{(34,35)}$. 
Apoptotic programs fall broadly into either the extrinsic or intrinsic category. Evasion of apoptosis is believed to be one of the hallmarks of cancers. Apoptosis, is controlled by caspases, which are divided into two classes: initiator (apical) caspases (caspase 2, 8, 9 and 10) and effector (executioner) caspases (caspase 3,6 and 7) ${ }^{(36)}$.

In a resting cell, caspase 9 exists as an inactive monomer in the cytoplasm and is part of the intrinsic pathway of apoptosis. A cell experiencing stress first releases cytochrome $c$ from the mitochondria. The binding of cytochrome $\mathrm{c}$ to the APAF1 monomer leads to a serial conformational changes that activate APAF1. Then seven similarly activated APAF1 monomers form an oligomeric complex, the center of which contains the CARDs that recruit and activate caspase 9 . The complex containing cytochrome c, APAF1, and caspase 9 has been termed the apoptosome ${ }^{(37)}$.

Cell shrinkage and pyknosis are observable by light microscopy early during apoptosis. Pyknosis results from of chromatin condensation and is one of the most characteristic signs of apoptosis. Apoptotic cells also exhibit plasma membrane blebbing followed by karyorrhexis and separation of cell fragments into apoptotic bodies a process referred to as "budding." Apoptotic bodies consist of cytoplasm with tightly packed organelles with or without a nuclear fragment ${ }^{(38)}$.

In certain types of SCCs, the inhibition of caspase 9 activity and Apaf-1 expression may represent a mechanism of acquired cisplatin resistance. It has been reported that CisPt induced caspase 9 activation and apoptosis in cisplatin-sensitive SCCs in vitro. On the contrary, the cisplatin-resistant SCCs analyzed were not able to activate caspase 9 following CisPt treatment, thus not responding to therapy ${ }^{(39)}$.

That is why the use of adjuvants with CisPt has been studied heavily in recent years. However, the effect of MO in combination with other CisPt has not yet been studied in depth, for these reasons, the following work aimed to clarify the possible synergistic effect of both $\mathrm{MO}$ and $\mathrm{CisPt}$ as a novel treatment for squamous cell carcinoma.

\section{Aim of the work}

The aim of the present work was to;

- Assess the anti-carcinogenic potentiality of Moringa Oleifera extract in treatment of human squamous cell carcinoma.

- Assess the anti-carcinogenic potentiality of Moringa Oleifera extract in conjunction with different doses of Cisplatin in treatment of human squamous cell carcinoma cell line.

This would be assessed through;

1) Inverted phase contrast microscopy

2) Gene expression of caspase 9 by quantitative real-time reverse transcriptase PCR

3) Beta catenin protein by western blot analysis

4) Cell viability by MTT cell viability assay

\section{MATERIAL AND METHODS}

\section{A) Materials}

I) Moringa Oleifera leaves

II) Cisplatin ${ }^{\circledR}$ 10mg / 10 ML 1 VIAL (commercially available)

Manufacturer: Oncotec Pharma Produktion GmbH - ALLEMAGN

III) Cultured HEp2 Cells purchased from Vacera ${ }^{\circledR}$, Egypt

\section{B) Methods}

1-Preparation of Moringa Oleifera extract:

This procedure was performed at the National Research Centre Department of Pharmacology. The air dried powdered leaves of Moringa Oleifera were exhaustively extracted with $80 \%$ methanol in $\mathrm{H}_{2} \mathrm{O}$ by percolation at room temperature. The hydroalcoholic extract was filtered and evaporated 
under reduced pressureat $40^{\circ} \mathrm{C}$ to yield a dark residue of $400 \mathrm{mg}$ MoringaOleifera extract. The concentration used was $10 \mathrm{U} / \mathrm{mL}$.

2-Cultures of Human squamous cell carcinoma (HEp2) were purchased from the American Type Culture Collection (ATCC). The cells were cultured in a sterile $50 \mathrm{~cm}^{2}$ tissue culture flask in complete medium containing Dulbecco's modified Eagle's medium (DMEM) supplemented with 10\% FBS and antibiotics $(100 \mathrm{U} / \mathrm{mL}$ penicillin and $100 \mathrm{~g} / \mathrm{mL}$ streptomycin)in $95 \%$ air $/ 5 \% \mathrm{CO}_{2}$ at $37^{\circ} \mathrm{C}$. Cells were cultured to $100 \%$ confluence. Cells from passage 14 were used in this study.

\section{3-Grouping:}

The study comprised 2 control groups and ten experimental groups (table 1).

TABLE (1): Summary of control and experimental subgroups

\begin{tabular}{|l|l|}
\hline Subgroup & Details \\
\hline Subgroup HA & HEp2 after 24 hours. (control) \\
\hline Subgroup HB & HEp2 after 48 hours.(control) \\
\hline Subgroup MA & Moringa Oleifera extract after 24 hours \\
\hline Subgroup MB & Moringa Oleifera extract after 48 hours \\
\hline Subgroup C20A & Cisplatin 20 mg after 24 hours \\
\hline Subgroup C20B & Cisplatin 20 mg after 48 hours \\
\hline Subgroup C50A & Cisplatin 50 mg after 24 hours \\
\hline Subgroup C50B & Cisplatin 50 mg after 48 hours \\
\hline Subgroup M/C20A & $\begin{array}{l}\text { Moringa Oleifera extract + Cisplatin } \\
20 \text { mg after 24 hours }\end{array}$ \\
\hline Subgroup M/C20B & $\begin{array}{l}\text { Moringa Oleifera extract + Cisplatin } \\
20 \text { mg after 48 hours }\end{array}$ \\
\hline Subgroup M/C50A & $\begin{array}{l}\text { Moringa Oleifera extract + Cisplatin } \\
50 \text { mg after 24 hours }\end{array}$ \\
\hline 50 mg after 48 hours \\
\hline Subgroup M/C50B
\end{tabular}

Where A stands for 24 hours and B stands for 48 hours. $M$ stands for Moringa Oleifera extract, C20 for Cisplatin 20 $\mathrm{mg}$, C50 for Cisplatin $50 \mathrm{mg}, \mathrm{M} / \mathrm{C20}$ for Moringa Oleifera extract + Cisplatin $20 \mathrm{mg}$, M/C50 for Moringa Oleifera exract + Cisplatin50 $\mathrm{mg}$.

HEp2 cells were harvested for assessment of the following:

1) Inverted phase contrast microscopy

2) Gene expression of caspase 9 by real-time quantitative reverse transcription PCR

3) Beta catenin protein by western blot analysis

4) Cell viability by MTT cell viability assay

\section{Real-time quantitative reverse transcription polymerase chain reaction (RT-qPCR)}

Total RNA was extracted from cells sample using Qiagenekit(USA) according to a standard protocol. The isolated total RNA was converted into complementary DNA (cDNA) using Moloney murine leukemia virus (M-MLV) reverse transcriptase (Promega, Madison, USA) .Real-time PCR was performed using Step One Plus Real-Time PCR System (Applied Biosystems, Foster City, CA, USA) and an SYBR ${ }^{\circledR}$ Green PCR Master Mix (Applied Biosystems) in a final volume of $10 \mu \mathrm{l}$ with the following thermal cycling conditions: $95{ }^{\circ} \mathrm{C}$ for $10 \mathrm{~min}$, followed by 40 cycles of $95^{\circ} \mathrm{C}$ for $15 \mathrm{~s}$ and $60{ }^{\circ} \mathrm{C}$ for $1 \mathrm{~min}$. The sequences of PCR primer pairs used for each geneare shown in Table(2). Data were analyzed with the ABI Prism sequence detection system software and quantified using the v1.7 Sequence Detection Software from PE Biosystems (Foster City, CA). Relative expression of studied genes was calculated using the comparative threshold cycle method. All values were normalized to the beta actin genes as an invariant endogenous control (reference gene). The relative quantification was then calculated by the expression $2^{-\Delta \Delta \mathrm{Ct}}$. 
TABLE (2): Sequence of the primers used for realtime PCR

\begin{tabular}{|l|l|}
\hline & Primer sequence \\
\hline Caspase 9 & $\begin{array}{l}\text { Forward primer :5'-TCA TTA TTCAGG CCT } \\
\text { GCC GTG GTA-3' } \\
\text { Reverse primer:5'-TGG ATG AAC CAG GAG } \\
\text { CCA TCC TTT -3' }\end{array}$ \\
\hline Actin & $\begin{array}{l}\text { Forward primer : } \\
\text { 5'-TATCCTGGCCTCACTGTCCA-3' } \\
\text { Reverse primer:5'- } \\
\text { AACGCAGCTCAGTAACAGTC-3' }\end{array}$ \\
\hline
\end{tabular}

Pfaff M, 2001 ${ }^{(40)}$

\section{Western blot analysis}

Cellsproteins'wereextractedusingTRIzolreagent, and protein concentrations were estimated by the Bradford method. Twenty micrograms of protein per lane were separated with $10 \%$ SDSpolyacrylamide gel electrophoresis gels and electrophoretically transferred to polyvinylidenedifluoride (PVDF) membranes. Membranes were then incubated at room temperature for $2 \mathrm{~h}$ with blocking solution comprised of 5\% nonfat dried milk in 10 mMTris$\mathrm{Cl}, \mathrm{pH} 7.5,100 \mathrm{mMNaCl}$, and $0.1 \%$. Membranes were incubated overnight at $4{ }^{\circ} \mathrm{C}$ with the indicated primary antibodies (beta catenin and beta-actin) and then incubated with a mouse anti-rabbit secondary monoclonal antibody conjugated to horseradish peroxidase at room temperature for $2 \mathrm{~h}$. After each incubation, the membranes were washed four times with $10 \mathrm{mMTris}-\mathrm{Cl}$, pH 7.5, $100 \mathrm{mMNaCl}$, and $0.1 \%$ at room temperature Chemiluminescence detection was performed with the Amersham detection kit according to the manufacturer's protocols. The amount of studied protein was quantified by densitometric analysis using BioRadsoft ware, USA. Results were expressed as arbitrary units after normalization for $\beta$-actin protein expression.

\section{MTT Cell viability assay}

Cells in all groups were determined using the MTT (3-[4,5-dimethylthiazol-2-yl]-2.5-diphenyl tetrazolium bromide) cellproliferation kit (Trevigen
Inc., Gaithersburg, MD, USA)as per manufacturer's protocol. Briefly, cells were plated in a 96-well tissue culture plates in a range of 103-105 cells/ wellin a final volume of $100 \mathrm{uL}$ of medium and were allowedto attach overnight.

The MTT reagent is added (10ulperwell) and the plate is incubated for 2 to $12 \mathrm{~h}$ to allow for intracellular reduction of the soluble yellow MTT to theinsoluble purple formazan dye. Detergent reagent is added toeach well to solubilize the formazan dye prior to measuring theabsorbance of each sample in a micro platereaderat550-600 nm. Six wells were used for each group. Cell proliferation was assessed as the percentage of cell proliferation comparedto untreated HEp2 as control cells.

\section{Statistical Analysis}

The collected data was tabulated using Microsoft Excel (Microsoft Office 2007). All cases were included in the statistical analysis. The data was tabulated using the Statistical Package for Social Science (SPSS 15.0) Software. The mean values and standard errors were calculated for each time point from the pooled normalized data. The statistical tests performed included the One Way ANOVA and the two-tailed Student's T-test for comparison of means. The results were considered significant when the $P$ value was $\leq 0.05$. Graphs were performed using Microsoft power point software (Microsoft Office 2007).

\section{RESULTS}

\section{A) Invertedphase contrast microscopic results:}

\section{Control subgroups:}

After 24 hours, results of control subgroups showed, a relatively large number of HEp2 cells with few empty spaces in between, the cells were pleomorphic, few of which exhibited cytoplasmic processes (fibroblst-like) and some were closely packed. Fig. (1). While, after 48 hours, the results showed a relative confluence of the assessed HEp2 cells. Fig.(2). 


\section{Experimental subgroups:}

\section{Subgroups $M A$ and $M B$}

After 24 hours, examination of subgroup MA, revealed an apparently fewer number of widely spaced cells, the morphology of which was more or less polygonal with absence of cytoplasmic processes when compared to subgroups HA and HB (Fig. 3). However, after 48 hours of MO treatment the cells were relatively reduced in number and cells appeared to have shrunken in size compared to those after 24 hours of the same treatment

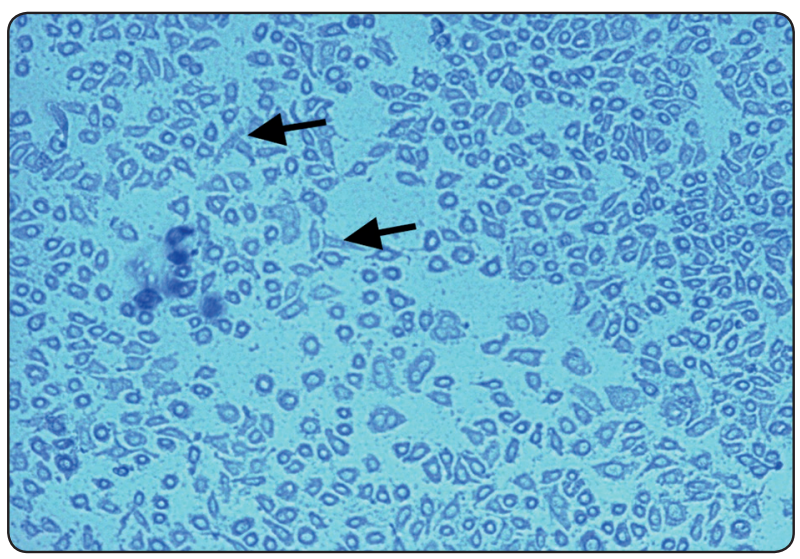

Fig. (1) A photomicrograph of subgroup HA of untreated HEp2 cells assessed after 24 hours, showing pleomorphic cells with few empty spaces. Also, note fibroblast like morphology of some cells (black arrows). (Org.mag.X200).

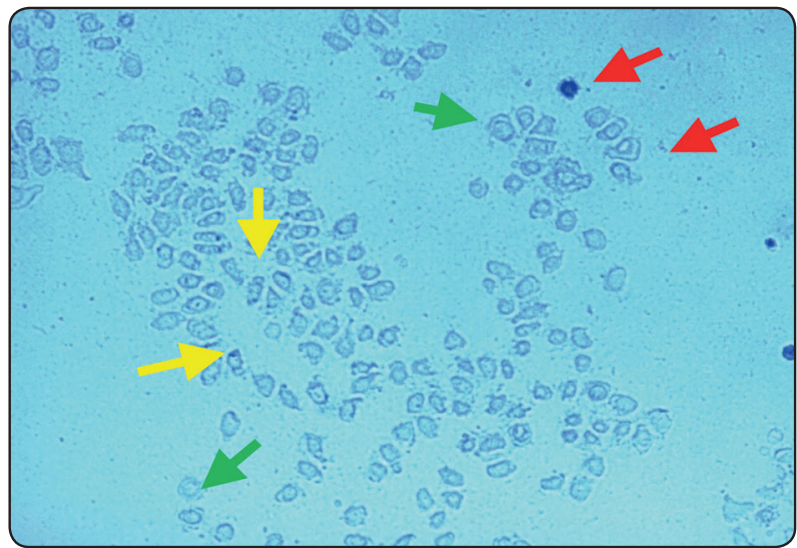

Fig.(3) Photomicrograph of subgroup MA, showing a relative reduction of the HEp2 cells. Note, nuclear condensation (red arrows) nuclear fragmentation (yellow arrows) and cytoplasmic pebbling (green arrows) (Org.mag.X200).
(Fig. 4). Also noted, were cytoplasmic pebbling, nuclear fragmentation and nuclear condensation of some of the cells in both groups.

\section{Subgroups C20A and C20B}

After 24 hours, of CisPt20mg treatment, the cells exhibited similar morpholgical features to those of the control subgroups.(Fig. 5) On the other hand, after 48 hours, of the same dose, the cells were comparetively smaller in size and much fewer in number and were more rounded with nuclear condensation(Fig.6)

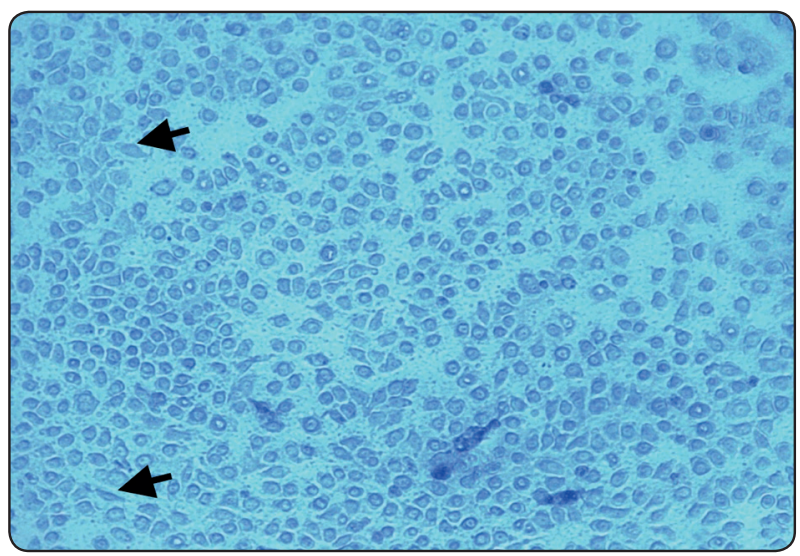

Fig. (2) A photomicrograph of subgroup HB of untreated HEp2 cells assessed after 48 hours, showing relative confluence of cells. Few cells with fibroblast like morphology were also noted (black arrows). (Org.mag.X200).

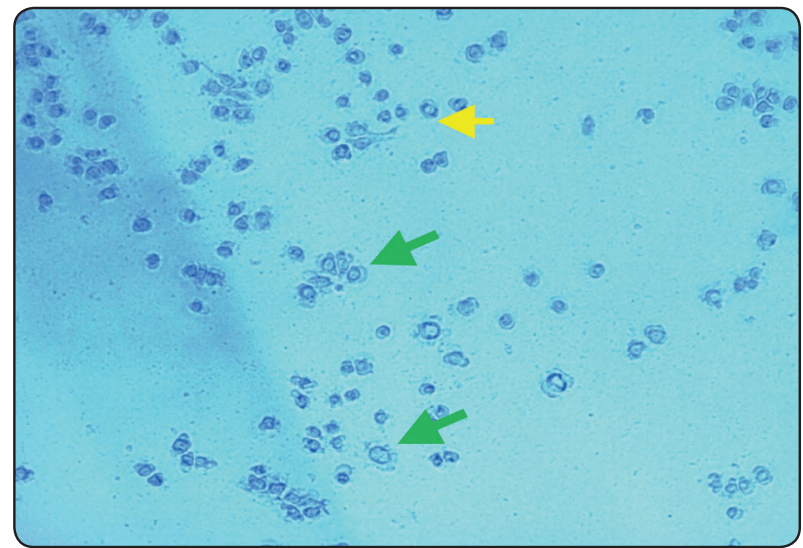

Fig.(4) Photomicrographof subgroup MBshowing a further reductionof HEp2 cells number and size. The cells exhibited nuclear fragmentation (yellow arrow) and cytoplasmic pebbling (green arrows).(Org.mag.X200). 


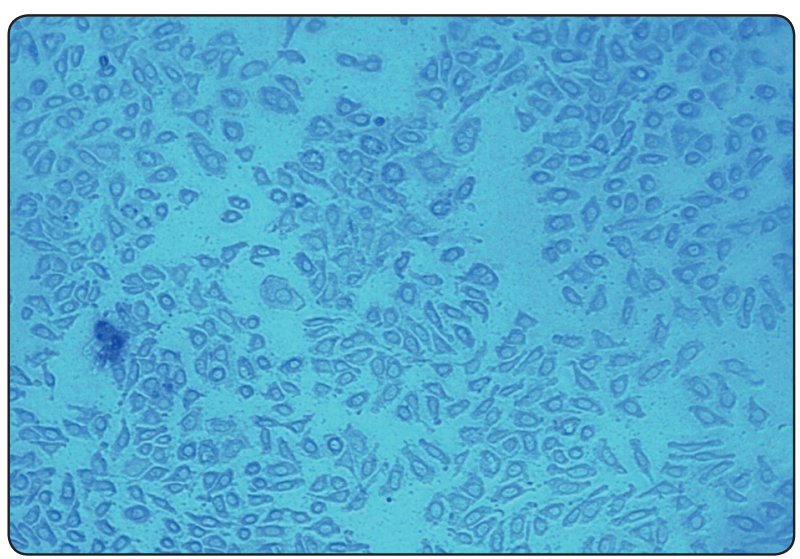

Fig. (5) Photomicrograph of subgroup C20A, showing a relatively confluent HEp2 cells. (Org.mag.X200).

\section{Subgroups C50A and C50B}

After 24 hours of CisPt50 mg treatment, the cells were apparently fewer in number, roundwith pebbling of the cytoplasm (Fig. 7). Whereas, after 48 hours of the same treatment, the cells showed relatively fewer cells than subgroup C50A, with apparently similar morphological patterns.(Fig. 8)

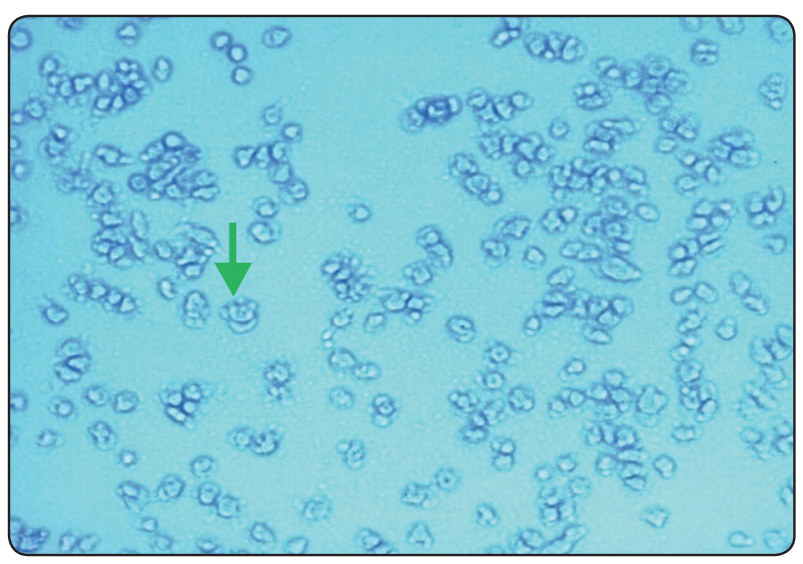

Fig.(7) Photomicrograph of subgroup C50A. The HEp2 cells were relatively fewer compared to the MA and C20A subgroups. Also note, the cells were round and exhibited cytoplasmic pebbling (green arrow). (Org.mag.X200).

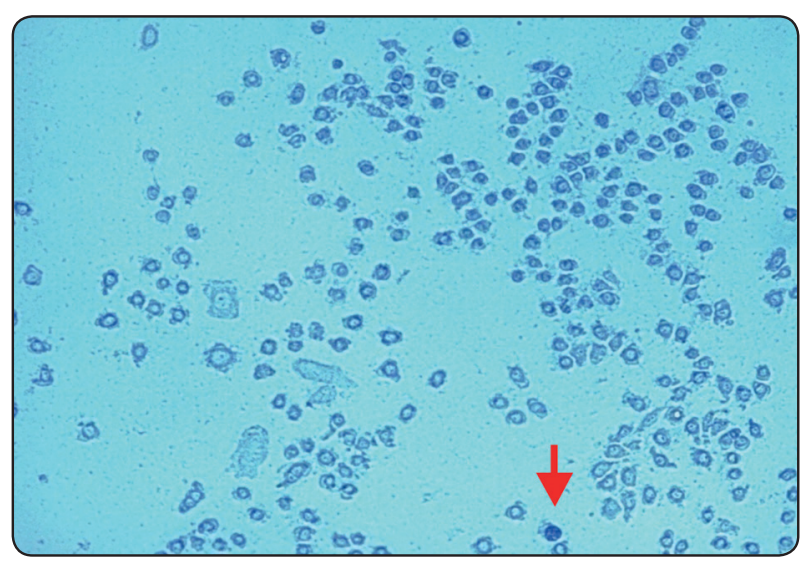

Fig. (6) Photomicrograph of subgroup C20B. Observed was nuclear condensation (red arrow) in some HEp2 cells (Org.mag.X200).

\section{Subgroups M/C20A and M/C20B}

After 24 hours of MO and CisPt20 mg treatment, the cells seemed to be few in number, round, with cytoplasmic pebbling and nuclear fragmentation (Fig. 9). While, after 48 hours of the same treatment, the cells appeared to have shrunken in size and became more round and dense, the nuclear condensation and fragmentation were relatively more pronounced in this subgroup than in the $\mathrm{M}$ / C20A subgroup.(Fig. 10)

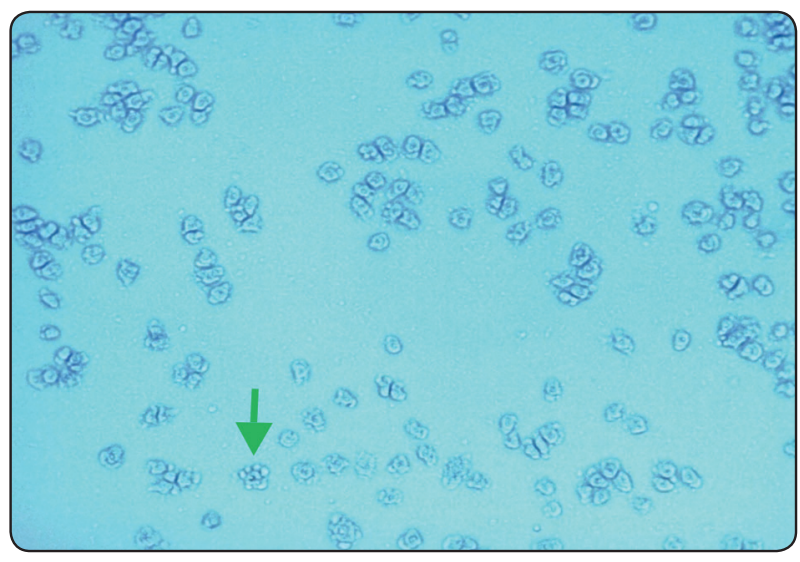

Fig.(8) Photomicrograph of subgroup C50B, showing relative reduction in the number of cells and cytoplasmic pebbling (green arrow) (Org.mag.X200). 


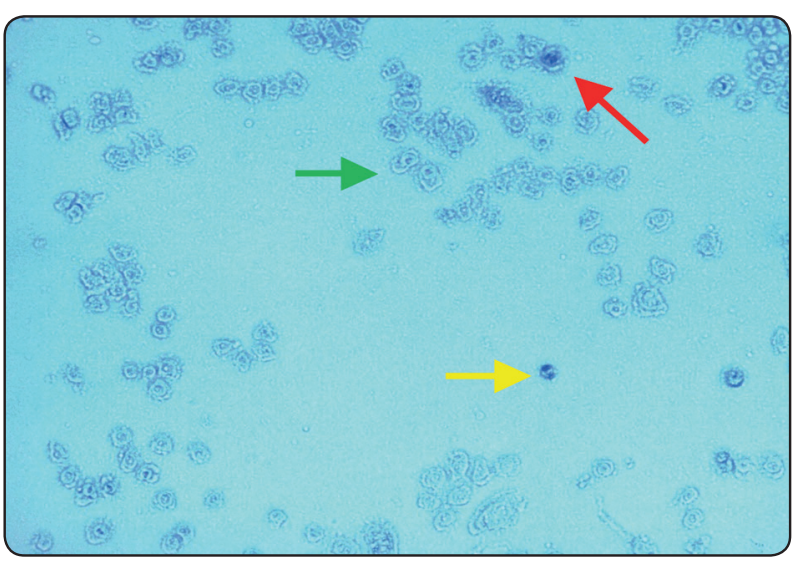

Fig.(9) Photomicrograph of subgroup M/C20A. The HEp 2 cells appeared to be even fewer than those of subgroup C50B. Also observed were, cytoplasmic pebbling (green arrow), nuclear condensation (red arrow) and fragmentation (yellow arrow) (Org.mag.X200).

\section{Subgroups M/C50A and M/C50B}

After 24 and 48 hours of MO and CisPt50 mg treatment, the cells appeared to morphologically resemble those noted in subgroups $\mathrm{M} / \mathrm{C} 20 \mathrm{~A}$ and

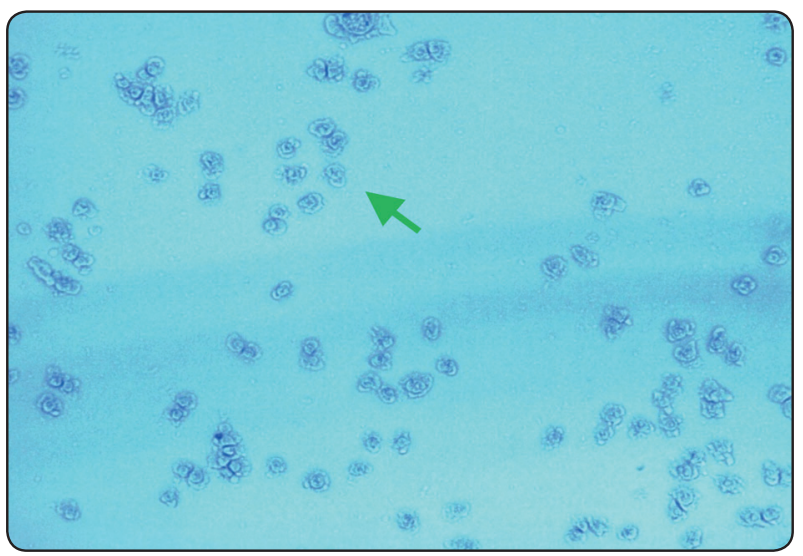

Fig. (11) Photomicrograph of subgroup M/C50A. The cells appear to morphologically resemble those noted in subgroups M/C20A with cytoplasmic pebbling (green arrow) (Org.mag.X200).

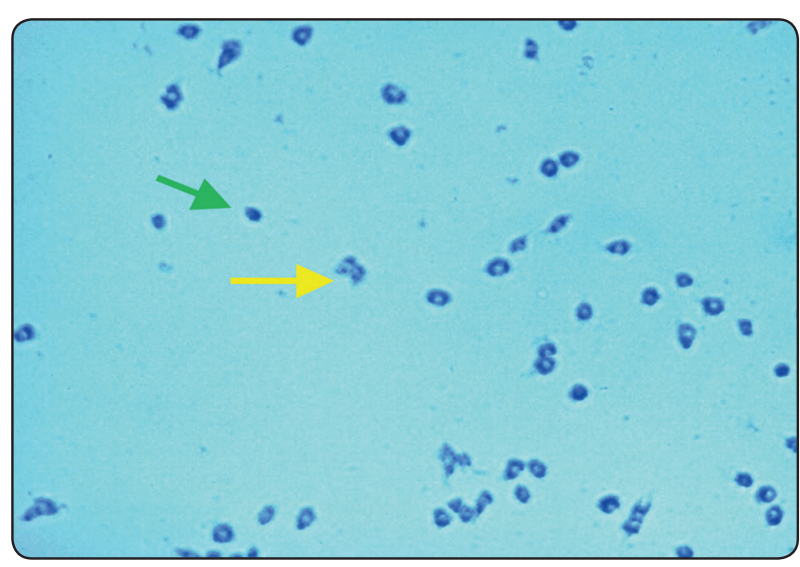

Fig.(10) Photomicrograph of subgroup M/C20B. The cells exhibited nuclear condensation (red arrow) and fragmentation (yellow arrow). (Org.mag.X200).

M/C20B, respectively (Fig. 11,12) but this subgroup exhibited the least number of cells per field among all the studied subgroups.

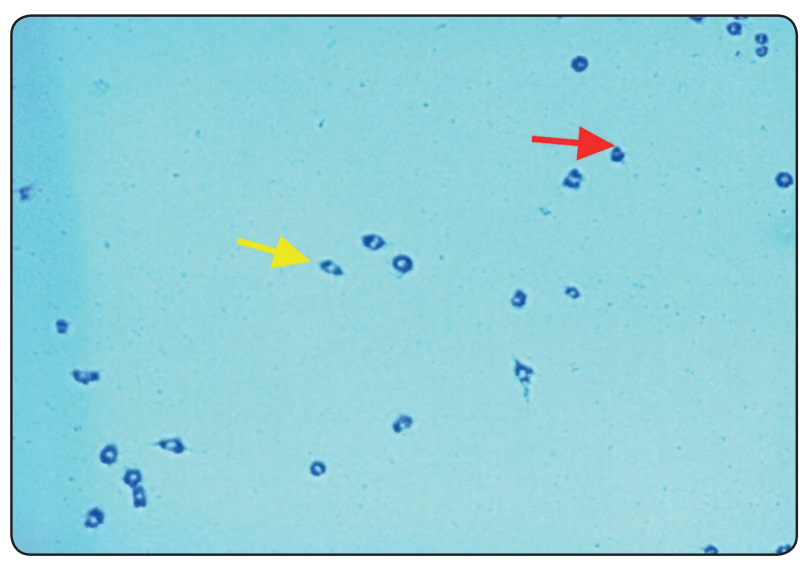

Fig. (12) Photomicrograph of subgroup M/CB50. Also noted were cells with nuclear condensation (red arrow) and fragmentation (yellow arrow) (Org.mag.X200). 


\section{B) STATISTICAL RESULTS}

\section{I ) PCR: Caspase 9:}

TABLE (3) ANOVA test between subgroups after 24 hours for Caspase 9 gene expression

\begin{tabular}{|c|c|c|c|}
\hline \multicolumn{2}{|l|}{} & ANOVA & Sig. \\
\hline Caspase 9 & Between Subgroups & 23.781 & .000 \\
\hline
\end{tabular}

TABLE (4) Mean values of Caspase 9 expression after 24 hours

\begin{tabular}{|l|c|}
\hline Subgroup & Mean gene expression \\
\hline HA & 1.0250 \\
\hline MA & 8.2750 \\
\hline C20A & 6.2825 \\
\hline C50A & 11.6000 \\
\hline M/C20A & 14.8000 \\
\hline M/C50A & 19.8750 \\
\hline
\end{tabular}

TABLE (5) T- test between subgroups tested after 24 hrs for Caspase 9 gene expression

\begin{tabular}{|l|l|c|}
\hline \multicolumn{2}{|c|}{ Subgroups } & P-value \\
\hline HA & MA & .021 \\
\hline HA & C20A & .205 \\
\hline HA & C50A & .000 \\
\hline HA & M/C20A & .000 \\
\hline HA & M/C50A & .000 \\
\hline MA & C20A & 1.000 \\
\hline MA & C50A & 1.000 \\
\hline MA & M/C20A & .049 \\
\hline MA & M/C50A & .000 \\
\hline C20A & C50A & .191 \\
\hline C20A & M/C20A & .005 \\
\hline C20A & M/C50A & .000 \\
\hline C50A & M/C20A & 1.000 \\
\hline C50A & M/C50A & .006 \\
\hline M/C20A & M/C50A & .250 \\
\hline
\end{tabular}

TABLE (6) ANOVA between subgroups tested after 48 hours for Caspase 9 gene expression

\begin{tabular}{|l|c|c|c|}
\hline \multicolumn{2}{|l|}{} & ANOVA & Sig. \\
\hline Caspase 9 & Between subgroups & 39.242 & .000 \\
\hline
\end{tabular}

TABLE (7): Caspase 9 gene expression after 48 hours

\begin{tabular}{|l|l|}
\hline Subgroup & Mean gene expression \\
\hline HB & 1.0275 \\
\hline MB & 10.7750 \\
\hline C20B & 9.6000 \\
\hline C50B & 15.2000 \\
\hline M/C20B & 19.4000 \\
\hline M/C50B & 23.5500 \\
\hline
\end{tabular}

TABLE (8) T- test between subgroups tested after 48 hrs for Caspase 9 gene expression

\begin{tabular}{|c|c|c|}
\hline \multicolumn{2}{|c|}{ Subgroups } & P-value \\
\hline $\mathrm{HB}$ & $\mathrm{MB}$ & .001 \\
\hline $\mathrm{HB}$ & $\mathrm{C} 20 \mathrm{~B}$ & .002 \\
\hline $\mathrm{HB}$ & $\mathrm{C} 50 \mathrm{~B}$ & .000 \\
\hline $\mathrm{HB}$ & $\mathrm{M} / \mathrm{C} 20 \mathrm{~B}$ & .000 \\
\hline $\mathrm{HB}$ & $\mathrm{M} / \mathrm{C} 50 \mathrm{~B}$ & .000 \\
\hline $\mathrm{MB}$ & $\mathrm{C} 20 \mathrm{~B}$ & 1.000 \\
\hline $\mathrm{MB}$ & $\mathrm{C} 50 \mathrm{~B}$ & .361 \\
\hline $\mathrm{MB}$ & $\mathrm{M} / \mathrm{C} 20 \mathrm{~B}$ & .002 \\
\hline $\mathrm{MB}$ & $\mathrm{M} / \mathrm{C} 50 \mathrm{~B}$ & .000 \\
\hline $\mathrm{C} 20 \mathrm{~B}$ & $\mathrm{C} 50 \mathrm{~B}$ & .089 \\
\hline $\mathrm{C} 20 \mathrm{~B}$ & $\mathrm{M} / \mathrm{C} 20 \mathrm{~B}$ & .001 \\
\hline $\mathrm{C} 20 \mathrm{~B}$ & $\mathrm{M} / \mathrm{C} 50 \mathrm{~B}$ & .000 \\
\hline $\mathrm{C} 50 \mathrm{~B}$ & $\mathrm{M} / \mathrm{C} 20 \mathrm{~B}$ & .467 \\
\hline $\mathrm{C} 50 \mathrm{~B}$ & $\mathrm{M} / \mathrm{C} 50 \mathrm{~B}$ & .003 \\
\hline $\mathrm{M} / \mathrm{C} 20 \mathrm{~B}$ & $\mathrm{M} / \mathrm{C} 50 \mathrm{~B}$ & .494 \\
\hline
\end{tabular}




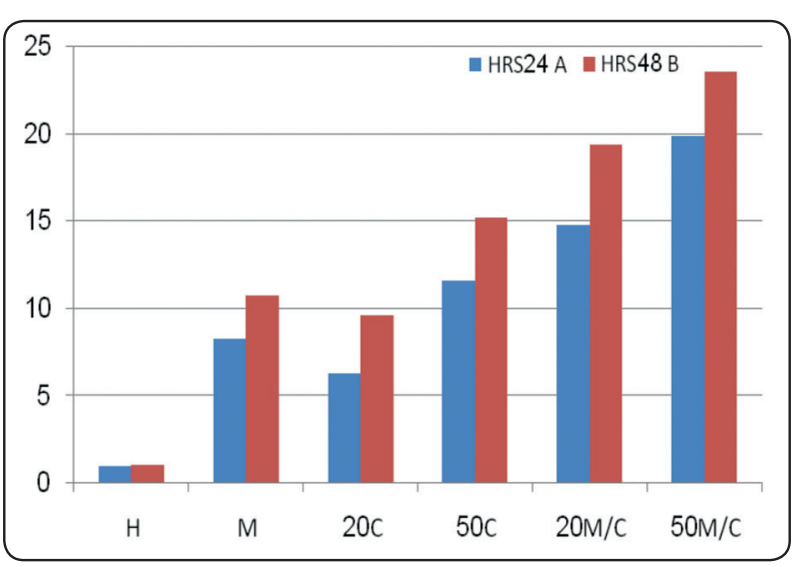

Fig. (13) Bar chart showing mean values of caspase 9 gene expression in the studied subgroups.

TABLE (9) T-test between the same subgroups at the two durations for Caspase 9 gene expression

\begin{tabular}{|l|l|l|}
\hline \multicolumn{2}{|l|}{ Subgroups } & P-value \\
\hline HA & HB & 0.911 \\
\hline MA & MB & 0.134 \\
\hline C20A & C20B & 0.121 \\
\hline C50A & C50B & 0.019 \\
\hline M/C20A & M/C20B & 0.074 \\
\hline M/C50A & M/C50B & 0.279 \\
\hline
\end{tabular}

Tables (4 and 7) and fig (13) showed the mean caspase 9 gene expression in each culture after 24 and 48 hours, respectively. Tables (3 and 6) showed the significance of difference in caspase 9 gene expression between the studied cultures after 24 and 48 hours, respectively, using One Way ANOVA test.

Tables (4 and 7), revealed that caspase 9 expression was lowest in the HA subgroup = 1.0250), followed by the HB subgroup $=1.0275$, respectively, but the difference between them was insignificant $(\mathrm{P}=0.911)$, using the student T-test. (Table 9)

Then came the C20A subgroup $=6.2825$, followed by the MA subgroup $=8.2750$ (table 4), and the difference between these two was also insignificant $(\mathrm{P}=1.00)$, using the student T-test. (Table 5). Also, the difference between the HA and C20A was insignificant (table 5)

The highest expression was M/C50B subgroup $=23.5500$ and the $\mathrm{M} / \mathrm{C} 20 \mathrm{~B}$ subgroup $=19.4000$, (table 7) but the difference between these two groups was insignificant $(\mathrm{P}=0.494)$, using the student T-test. (table 8)

Table (9), showed that the mean difference in caspase 9 gene expression values were insignificant when the duration was increased from 24 hours to 48 hours except, in the control subgroups ( $\mathrm{P}=0.019$ ), using the student T-test. For each group the Caspase gene expression always increased when the duration increased from 24 to 48 hours.

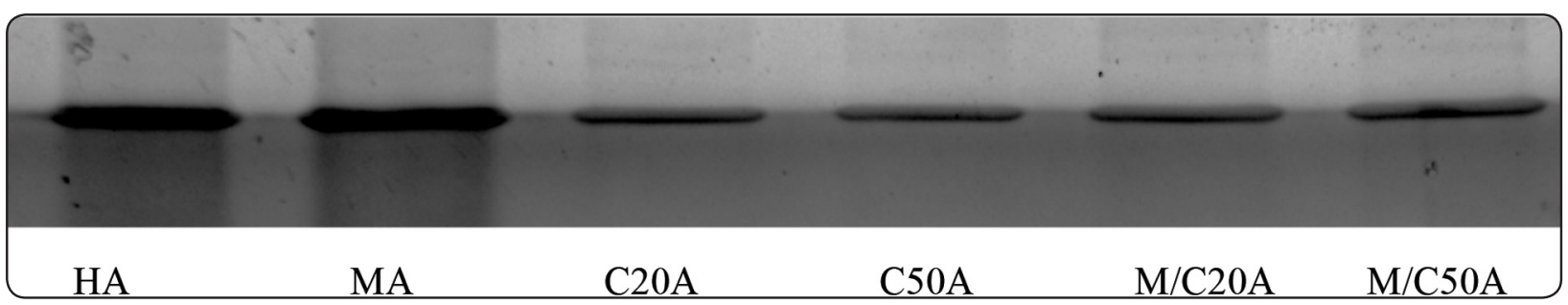

Fig. (14) Beta catenin protein assessed after 24 hours by western blotting, the thickest band width was noted in the HA and MA subgroups.

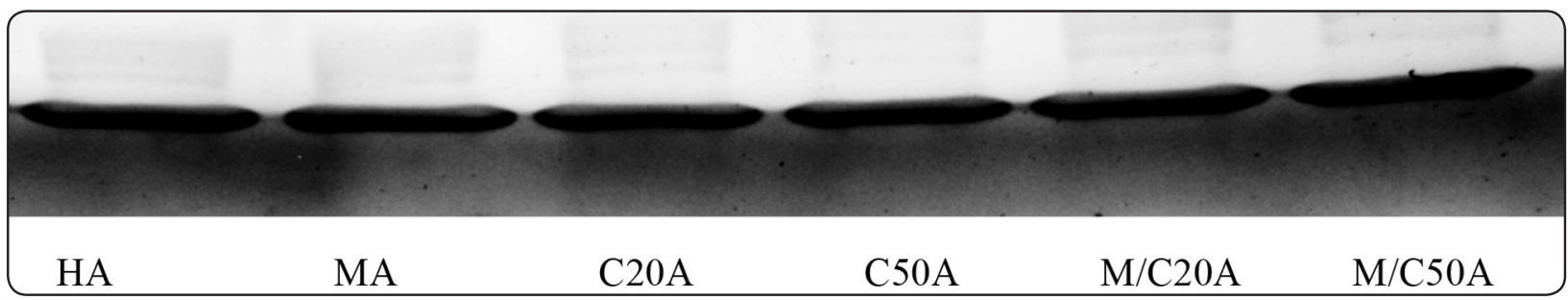

Fig. (15) $\beta$ actin protein 


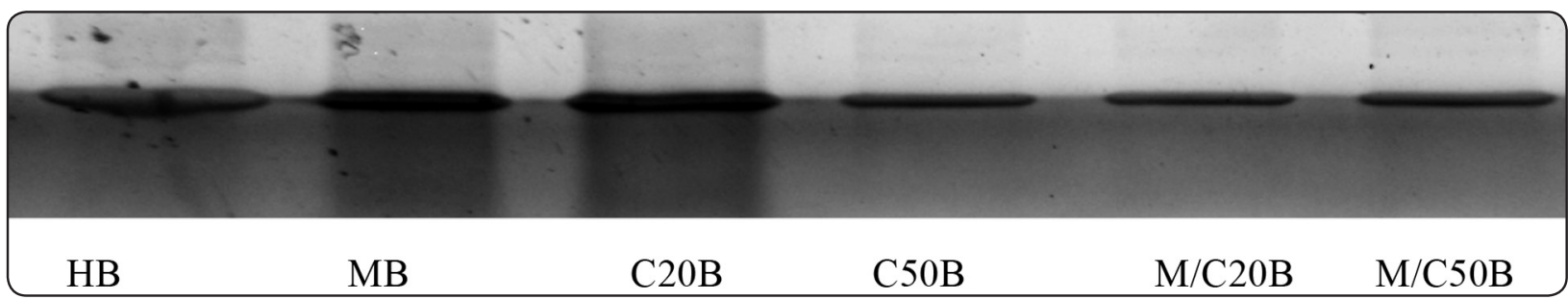

Fig. (16): Beta catenin protein assessed after 48 hours by western blotting, the thickest band width was noted in the HB and MB subgroups.

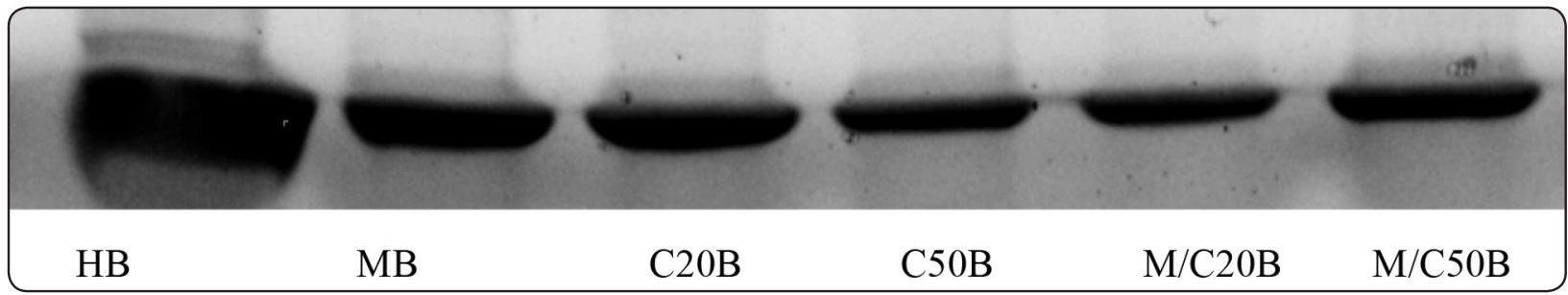

Fig. (17): $\beta$ actin protein

\section{II- Western blot: Beta catenin}

\section{Beta catenin protein after 24 hours}

TABLE (10) ANOVA between subgroups tested after 24 hours for Beta catenin protein

\begin{tabular}{|l|c|c|c|}
\hline & & ANOVA & Sig. \\
\hline Beta catenin & $\begin{array}{c}\text { between } \\
\text { subgroups }\end{array}$ & 25.521 & .000 \\
\hline
\end{tabular}

TABLE (11) Beta catenin protein after 24 hours

\begin{tabular}{|c|c|}
\hline Subgroup & Mean Beta catenin protein \\
\hline HA & 1.0225 \\
\hline MA & .6225 \\
\hline $\mathrm{C} 20 \mathrm{~A}$ & .6675 \\
\hline $\mathrm{C} 50 \mathrm{~A}$ & .4350 \\
\hline $\mathrm{M} / \mathrm{C} 20 \mathrm{~A}$ & .3500 \\
\hline $\mathrm{M} / \mathrm{C} 50 \mathrm{~A}$ & .2500 \\
\hline
\end{tabular}

TABLE (12) T- test between subgroups tested after 24 hrs for Beta catenin protein

\begin{tabular}{|c|c|c|}
\hline \multicolumn{2}{|c|}{ Subgroups } & P-value \\
\hline HA & MA & .001 \\
\hline HA & C20A & .004 \\
\hline HA & C50A & .000 \\
\hline HA & M/C20A & .000 \\
\hline HA & M/C50A & .000 \\
\hline MA & C20A & 1.000 \\
\hline MA & C50A & .400 \\
\hline MA & M/C20A & .038 \\
\hline MA & M/C50A & .002 \\
\hline C20A & C50A & .117 \\
\hline C20A & M/C20A & .010 \\
\hline C20A & M/C50A & .001 \\
\hline C50A & M/C20A & 1.000 \\
\hline C50A & M/C50A & .428 \\
\hline M/C20A & M/C50A & 1.000 \\
\hline
\end{tabular}


TABLE (13) ANOVA between subgroups tested after 48 hours for Beta catenin protein

\begin{tabular}{|l|l|l|l|}
\hline & & ANOVA & Sig. \\
\hline Beta catenin & Between subroups & 32.032 & .000 \\
\hline
\end{tabular}

TABLE (14) Mean Beta catenin protein after 48 hours

\begin{tabular}{|c|c|}
\hline Subgroup & Mean Beta catenin protein \\
\hline $\mathrm{HB}$ & 1.0250 \\
\hline $\mathrm{MB}$ & .6525 \\
\hline $\mathrm{C} 20 \mathrm{~B}$ & .7250 \\
\hline $\mathrm{C} 50 \mathrm{~B}$ & .2875 \\
\hline $\mathrm{M} / \mathrm{C} 20 \mathrm{~B}$ & .1725 \\
\hline $\mathrm{M} / \mathrm{C} 50 \mathrm{~B}$ & .1350 \\
\hline
\end{tabular}

TABLE (15) T- test between subgroups tested after $48 \mathrm{hrs}$ for Beta catenin protein

\begin{tabular}{|c|c|c|}
\hline \multicolumn{2}{|c|}{ Subgroups } & \multirow{2}{*}{$\begin{array}{l}\text { P-values } \\
.008\end{array}$} \\
\hline HB & MB & \\
\hline $\mathrm{HB}$ & $\mathrm{C} 20 \mathrm{~B}$ & .051 \\
\hline HB & C50B & .000 \\
\hline $\mathrm{HB}$ & $\mathrm{M} / \mathrm{C} 20 \mathrm{~B}$ & .000 \\
\hline HB & $\mathrm{M} / \mathrm{C} 50 \mathrm{~B}$ & .000 \\
\hline MB & $\mathrm{C} 20 \mathrm{~B}$ & 1.000 \\
\hline MB & C50B & .010 \\
\hline MB & $\mathrm{M} / \mathrm{C} 20 \mathrm{~B}$ & .001 \\
\hline MB & $\mathrm{M} / \mathrm{C} 50 \mathrm{~B}$ & .000 \\
\hline $\mathrm{C} 20 \mathrm{~B}$ & C50B & .002 \\
\hline $\mathrm{C} 20 \mathrm{~B}$ & $\mathrm{M} / \mathrm{C} 20 \mathrm{~B}$ & .000 \\
\hline $\mathrm{C} 20 \mathrm{~B}$ & $\mathrm{M} / \mathrm{C} 50 \mathrm{~B}$ & .000 \\
\hline C50B & $\mathrm{M} / \mathrm{C} 20 \mathrm{~B}$ & 1.000 \\
\hline $\mathrm{C} 50 \mathrm{~B}$ & $\mathrm{M} / \mathrm{C} 50 \mathrm{~B}$ & 1.000 \\
\hline M/C20B & $\mathrm{M} / \mathrm{C} 50 \mathrm{~B}$ & 1.000 \\
\hline
\end{tabular}

Fig. (18): Bar chart showing mean values of Beta catenin protein in the studied subgroups.

Tables (11 and 14) and fig (18) showed the mean Beta catenin protein in each group after 24 and 48 hours, respectively. Tables (10 and 13) show the significance of difference in Beta catenin protein between the studied groups after 24 and 48 hours, respectively, using One Way ANOVA test.

The results showed that Beta catenin protein was highest in the HB subgroup $=1.0250$, (table 14) followed by HA subgroup = 1.0225 (table 11), and the difference between them was insignificant $(\mathrm{P}=$ 0.935), using the student T-test.(table 16)

Then came the $\mathrm{C} 20 \mathrm{~B}=0.7250$ (table 14), followed by $\mathrm{C} 20 \mathrm{~A}=0.6675$ (table 11 ), and the difference between these two was insignificant $(\mathrm{P}=$ 0.468), using the student T-test. (table 16) 
The lowest expression was seen in M/C50B $=0.1350$ and the $\mathrm{M} / \mathrm{C} 20 \mathrm{~B}=0.1725$ (Table 14), but the difference between these two groups was insignificant $(\mathrm{P}=1.000)$, using the student T-test. (table 15)

Table (16), showed that the mean difference in Beta catenin expression values were insignificant when the duration was increased from 24 hours to 48 hours except for $\mathrm{C} 20$ ( $\mathrm{P}=0.039)$, using the student T-test. For each group the Beta catenin protein always increased when the duration increased from 24 to 48 hours.

\section{III) MTT assay mean values}

Table (17) ANOVA between subgroups tested after 24 hours MTT assay

\begin{tabular}{|c|c|c|c|}
\hline & & ANOVA & Sig. \\
\hline MTT & Between Subgroups & 11.127 & .000 \\
\hline
\end{tabular}

Table (18): MTT mean values after 24 hours

\begin{tabular}{|l|c|}
\hline \multicolumn{1}{|c|}{ Subgroup } & Mean MTT value \\
\hline HA & 98.150 \\
\hline MA & 84.075 \\
\hline C20A & 85.950 \\
\hline C50A & 79.450 \\
\hline M/C20A & 70.825 \\
\hline M/C50A & 65.475 \\
\hline
\end{tabular}

TABLE (19) T-test between subgroups tested after 24 hrs for MTT assay

\begin{tabular}{|l|l|l|}
\hline \multicolumn{2}{|l|}{ Subgroups } & P-value \\
\hline HA & MA & .157 \\
\hline HA & C20A & .350 \\
\hline HA & C50A & .020 \\
\hline HA & M/C20A & .000 \\
\hline HA & M/C50A & .000 \\
\hline MA & C20A & 1.000 \\
\hline MA & C50A & 1.000 \\
\hline MA & M/C20A & .224 \\
\hline MA & M/C50A & .021 \\
\hline C20A & C50A & 1.000 \\
\hline C20A & M/C20A & .099 \\
\hline C20A & M/C50A & .009 \\
\hline C50A & M/C20A & 1.000 \\
\hline C50A & M/C50A & .164 \\
\hline M/C20A & M/C50A & 1.000 \\
\hline
\end{tabular}

TABLE (20) ANOVA between subgroups tested after 24 hours MTT assay

\begin{tabular}{|c|c|c|c|}
\hline & & ANOVA & Sig. \\
\hline MTT & Between Subgroups & 47.045 & .000 \\
\hline
\end{tabular}

TABLE (21): MTT mean values After 48 hours

\begin{tabular}{|l|c|}
\hline Subgroups & Mean MTT values after 48 hours \\
\hline HB & 99.025 \\
\hline MB & 78.625 \\
\hline C20B & 76.675 \\
\hline C50B & 57.650 \\
\hline M/C20B & 54.050 \\
\hline M/C50B & 47.650 \\
\hline
\end{tabular}


TABLE (22) T- test between subgroups tested after $48 \mathrm{hrs}$ for MTT assay

\begin{tabular}{|c|c|c|}
\hline \multicolumn{2}{|c|}{ Subgroups } & \multirow{2}{*}{$\begin{array}{c}\text { P-value } \\
.001\end{array}$} \\
\hline $\mathrm{HB}$ & MB & \\
\hline $\mathrm{HB}$ & C20B & .000 \\
\hline $\mathrm{HB}$ & C50B & .000 \\
\hline $\mathrm{HB}$ & $\mathrm{M} / \mathrm{C} 20 \mathrm{~B}$ & .000 \\
\hline $\mathrm{HB}$ & $\mathrm{M} / \mathrm{C} 50 \mathrm{~B}$ & .000 \\
\hline MB & C20B & 1.000 \\
\hline MB & C50B & .001 \\
\hline MB & $\mathrm{M} / \mathrm{C} 20 \mathrm{~B}$ & .000 \\
\hline MB & $\mathrm{M} / \mathrm{C} 50 \mathrm{~B}$ & .000 \\
\hline $\mathrm{C} 20 \mathrm{~B}$ & $\mathrm{C} 50 \mathrm{~B}$ & .002 \\
\hline $\mathrm{C} 20 \mathrm{~B}$ & $\mathrm{M} / \mathrm{C} 20 \mathrm{~B}$ & .000 \\
\hline $\mathrm{C} 20 \mathrm{~B}$ & $\mathrm{M} / \mathrm{C} 50 \mathrm{~B}$ & .000 \\
\hline C50B & $\mathrm{M} / \mathrm{C} 20 \mathrm{~B}$ & 1.000 \\
\hline C50B & $\mathrm{M} / \mathrm{C} 50 \mathrm{~B}$ & .325 \\
\hline $\mathrm{M} / \mathrm{C} 20 \mathrm{~B}$ & $\mathrm{M} / \mathrm{C} 50 \mathrm{~B}$ & 1.000 \\
\hline
\end{tabular}

TABLE (23) T- test between the same subgroups at the two durations for MTT assay

\begin{tabular}{|c|c|c|}
\hline \multicolumn{2}{|c|}{ Subgroup } & P-value \\
\hline $\mathrm{HA}$ & $\mathrm{HB}$ & .314 \\
\hline $\mathrm{MA}$ & $\mathrm{MB}$ & .216 \\
\hline $\mathrm{C} 20 \mathrm{~A}$ & $\mathrm{C} 20 \mathrm{~B}$ & .068 \\
\hline $\mathrm{C} 50 \mathrm{~A}$ & $\mathrm{C} 50 \mathrm{~B}$ & .001 \\
\hline $\mathrm{M} / \mathrm{C} 20 \mathrm{~A}$ & $\mathrm{M} / \mathrm{C} 20 \mathrm{~B}$ & .036 \\
\hline $\mathrm{M} / \mathrm{C} 50 \mathrm{~A}$ & $\mathrm{M} / \mathrm{C} 50 \mathrm{~B}$ & .024 \\
\hline
\end{tabular}

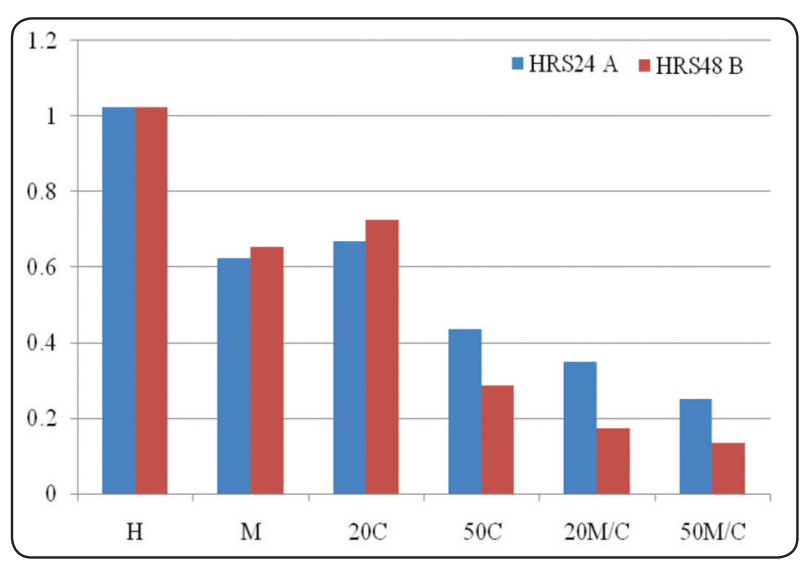

Fig. (19) Bar chart showing mean values of MTT assay in the studied groups.

Tables (18 and 21) and fig (19) show the mean MTT assay values in each subgroups after 24 and 48 hours, respectively. Tables (17 and 20) show the significance of difference in MTT assay values between the studied subgroups after 24 and 48 hours, respectively, using One Way ANOVA test.

The results showed that MTT assay values was highest in the HB $=99.025$ (table 21), followed by $\mathrm{C} 20 \mathrm{~A}=85.950$ (table 18). Then came the MA = 84.075 , followed by the C50A $=79.450$ (table 18), and the difference between latter three subgroups was insignificant $(\mathrm{P}=1.000)$, using the student T-test. (table19)

The lowest MTT assay value was seen in M/ $\mathrm{C} 50 \mathrm{~B}=47.650$ and $\mathrm{M} / \mathrm{C} 20 \mathrm{~B}=54.050$ (table 21), but the difference between these two subgroups was insignificant $(\mathrm{P}=1.000)$, using the student T-test. (table 22)

Table (23), shows that the mean MTT assay values for the same subgroup always decreased from 24 to 48 hours except for the $\mathrm{H}$ subgroup (control group). The mean difference in MTT assay values were significant when the duration was increased from 24 hours to 48 hours, in the C50 subgroup (P $=0.001), \mathrm{M}$ and $\mathrm{C} 20$ subgroups $(\mathrm{P}=0.036)$ and $\mathrm{M} /$ C50 subgroup ( $\mathrm{P}=0.024)$, using the student T-test. 


\section{DISCUSSION}

MO is a tree that is grown in many tropical countries. The pods, leaves and flowers of this tree are used widely in the Asian diet. Added to its amazing nutritional components, it is easily grown even in poor soils and dry weathers, and studies have also shown that extracts of MO leaves can be used to inhibit the proliferation of cancer cells. Moreover, MO was proven to increase ROS production that is specific and targets only cancer cells, thus making it an ideal anticancer agent ${ }^{(5)}$. That is why in this study MO was assessed as a potential natural treatment or adjunct to the traditional chemotherapeutic treatment of cancer.

CisPt is an anti-cancer chemotherapeutic agent that has been widely used to treat SCC for several years ${ }^{(41)}$. The side effects and drug resistance are concerns when this drug is prescribed. CisPt mechanism of action, is mainly through cell cycle arrest induced by DNA damage. Side effects develop because this DNA damage is not restricted to cancer cells; but the continuously proliferating normal cells are affected as well ${ }^{(15)}$.

CisPt can cause severe kidney problems or allergic reactions. Hearing problems (more common in children), bone marrow suppression, or severe nausea and vomiting may also occur. The risk of developing these side effects increases as the dose or total amount of CisPt used over time increases ${ }^{(42)}$. This study focused on whether the use of MO will potentiate the effect of CisPt and thus maybe allowing a reduction in the CisPt dose and associated side effects. In this study the cancer cell line was assessed after 24 hours then again after 48 hours to evaluate whether the out-come changed when treatment continued for another day, this was in accordance to the work done by Andriani et al, 2006 ; Bae-jump et al, 2009(43,44).

Researchers have been testing the effectiveness of using CisPt at $20 \mathrm{mg}$ with other treatment modalities ${ }^{(45)}$. Recently, it was stated that there is a known steep dose toxicity relationship for platinum compounds specifically beyond $50 \mathrm{mg} / \mathrm{m} 2$ due to CisPt renal toxicity ${ }^{(46)}$. Thus, it is best to try not to exceed this dose. Also several studies have stated that the side effects of CisPt especially the nephrotoxicity are cumulative, thus if the dose could be reduced, there will be an overall cumulative reduction. This study was done to assess whether the effectiveness of the higher CisPt dose $(50 \mathrm{mg})$ could be attained using the lower CisPt dose (20 $\mathrm{mg}$ ) and MO. Not just that, but there is an assumption that the vitamin E components of MO reduce the CisPt induced nephrotoxicity, this is beyond the scope of this study ${ }^{(47)}$.

The vast majority of the head and neck cancers are squamous cell carcinomas (SCC). Although treatments have greatly improved in the past few years, the survival rate in patients with advanced SCC is still poor. For these reasons SCC cell line (HEp2) was used in this study.

The results of this study showed that the lowest caspase 9 gene expression, highest Beta catenin protein and highest cell viability was always noted in HB followed by the HA subgroups, and the differences between them was always insignificant.

The reasons for this low caspase 9 gene expression may be due to AKT activation which has been proved to down regulate caspase 9 in human cancers, however, the exact mechanism is not yet fully elucidated ${ }^{(48)}$. As for the increased Beta catenin protein, the reason may be that mutations of Beta catenin are frequently encountered in cancers, generating mutant Beta catenin that escapes phosphorylation and degradation ${ }^{(29)}$.

Phase contrast microscopic results showed that, the highest relative cellular density among all the studied subgroups to be in the control subgroups. Also, noted were some cells exhibiting fibroblast like morphology, this may be a sign of epithelial mesenchymal transition (EMT) that may be attributed to the elevated Beta catenin protein and 
translocation from cell membrane that is associated with several cancers ${ }^{(14,26,49)}$.

The results of this study, illustrated that MO upregulatedcaspase 9 gene expression, reduced Beta catenin protein and reduced the viability of cancer cells when compared to the control subgroups.The reason behind this may be attributed to its high content of flavonoids like quercetin, glucosinolates such as ITCs, $\gamma$-tocopherol and the release of $\operatorname{ROS}^{(5,50,51)}$.

The results observed in this study when the cell line was treated with MO may be due to the fact that flavonoids can cause cell cycle arrest and induce apoptosis ${ }^{(50,52,53)}$. Quercetin as well as $\gamma$-tocopherols are able to interact with Beta catenin and block binding between Beta catenin and TCF and thus reducing proliferation and $\mathrm{EMT}^{(52,54,55)}$. It has also been demonstrated that quercetin induces apoptosis through a caspase 3 and caspase 9 dependent mechanism by releasing cytochrome $\mathrm{c}^{(56)}$. Furthermore, Quercetin was proved to block the AKT signaling pathway and thus upregulated caspases $9^{(52)}$. In addition, ITCs in MO inhibits proliferation of cancer cells also through AKT down regulation and induces apoptosis through caspase 9 upregulation ${ }^{(11)}$.

MO was also proved to induce ROS which subsequently resulted in DNA damage and apoptosis which may explain the upregulation of caspases 9, recorded in this subgroup as opposed to the control subgroups ${ }^{(5)}$. In addition, ROS maybe one of the reasons behind the reduced Beta catenin protein noted in this subgroup beyond the control subgroups. According to Boonstra et al, 2004(9) and Olmeda et al, $2003^{(34)}$, who stated that ROS production resulted in a G1 phase cell cycle arrest with subsequent low Beta catenin levels as the latter is rapidly declined in this phase of the cell cycle.

Treating the HEp2 cell line with CisPt resulted in upregulation of caspase 9 gene expression, downregulation of Beta catenin protein and reduction of the overall HEp2 cell viability when compared to the control subgroups in this study.
It should be noted never the less, that these results appeared to be time and dose dependant, the results improved (increased caspase 9 and reduced Beta catenin and cell viability) with increase in dose and time.

This correlated with the inverted phase microscope results for these subgroups, where there was a relative reduction in cellular density per examined fields and in the $\mathrm{C} / 20 \mathrm{~B}, \mathrm{C} 50 \mathrm{~A}$ and $\mathrm{C} / 20 \mathrm{~B}$ subgroups there were morphological changes noted that are consistent with apoptosis. Similar morphological changes were also reported by Karim et al, 2016 ${ }^{(57)}$, in a study about MO.

In this study however, for the $\mathrm{C} / 20 \mathrm{~A}$ subgroup, the cellular density appeared to be close to that observed in the control subgroups, this may be due to the fact that the CisPt20mg dose is not effective in a single dose and that the cumulative effect after two consecutive days proved to be more effective. Also some cells in this subgroup exhibited fibroblast like morphology similar to those noted in the HA and HB subgroups, this correlated with the fact that in this group also the Beta catenin protein still showed a relatively high expression as compared to the rest of the subgroups.

CisPt's mechanism of action is by forming DNA adducts, which eventually activates apoptosis, this explains why caspase 9 gene expression was observed to be high in the subgroups treated with CisPt. These results were consistent with Kuwahara et $\boldsymbol{a l}, \mathbf{2 0 0 0 ^ { ( 5 8 ) }}$, who stated that CisPt induced apoptosis in SCC cell lines, through Caspase 3, 8 and 9 activation, in a dose-dependent manner ${ }^{(58)}$. Moreover, activation of the $\mathrm{P} 53$ protein by damage recognition proteins results in, BAX activation, cytochrome $\mathrm{C}$ release and upregulation of caspase 9 , also, activated p53 can downregulate Beta catenin by a inducing the formation of the degradation complex ${ }^{(13,14)}$.

CisPt also induces ROS that trigger cell death. Omori et al, 2011 ${ }^{(59)}$, proved that ROS resulted in caspase dependent Beta catenin degradation which may be another mechanism for the reduction of 
Beta catenin protein observed in this study, after CisPt treatment ${ }^{(59)}$.

CisPt and MO combined application on HEp2 cell line, in this study, resulted in better outcomes than when either of them was used separately. The highest caspase 9 and the least Beta catenin protein and viability was recorded in the M/C50B subgroup. Also, the results demonstrated that even though the $\mathrm{M} / \mathrm{C} 50 \mathrm{~B}$ showed better results the differences between it and the M/C20 B was always insignificant. This shows that the addition of MO potentiated the effectiveness of CisPt on the cancer cell line.

Several researchers have proved that, AKT and B catenin upregulation by cancer cells cause resistance to CisPt effectiveness ${ }^{(19,20)}$, thus it may be postulated that as $\mathrm{MO}$ reduces the expression of these proteins it helps CisPt by lowering the resistance.

The fact that MO induces ROS and so does CisPt, may explain why the results of this study show that, MO potentiates the action of CisPt. ROS`s influence on cell cycle progression depends upon the amount and duration of ROS exposure ${ }^{(9)}$. Excessive ROS promotes cytochrome $\mathrm{c}$ to be released into the cytoplasm and triggers programmed cell death. It has been proved recently that the anti-cancer roles of ROS depend greatly on its concentration ${ }^{(6)}$.

Cancer cells are selectively sensitive to the damaging effects of ROS.This may be a consequence of the Warburg Effect that may affect the homeostasis of ROS generation by affecting the concentration of reducing equivalents in the mitochondria ${ }^{(60)}$.

Moreover, MO is rich in ITCs. These compounds have recently been proved to exert an epigenetic effect via modulation of DNA methylation. A study by $\mathrm{Lu}$ et al., 2008, examined the effect of ITC on myeloma cells, where it was found to induce DNA demethylation of the p16 gene, which led to reactivation of this tumor suppressor gene in myeloma cells. A similar mechanism may have taken place in this study and thus allowing CisPt induced apoptosis to be potentiated via the epigenetic changes in the HEp2 cells ${ }^{(61)}$.
Phase contrast microscopic results in this study revealed that HEp2 cells treated of the combined treatments (different doses and different durations) revealed apparent morphological changes from the control subgroups, this observation was consisted with those of Sethi et al, 2012, who observed nuclear and cytoplasmic vacuolation, shrinkage of tumor cells with nuclear changes that are consistent with apoptosis, like karyorrhexis, pyknosis and karyolysis, in cancer cells when treated with a neoadjuvnt chemotherapeutic agent. These changes are all associated with degenerative changes of the cancer cells ${ }^{(62)}$.

Despite the fact that, the best results (highest caspase 9, lowest Beta catenin and lowest viability) were obtained when the HEp 2 cells were treated with CisPt $50 \mathrm{mg}$ and $\mathrm{MO}$ and when the HEp 2 cells were treated with CisPt $50 \mathrm{mg}$, treatment using $\mathrm{MO}$ and CisPt $20 \mathrm{mg}$ should be thoroughly considered for the following reasons. First of all the difference in results between these groups was always insignificant (when treated for the same duration) and secondly the lowered dose of CisPt and the use of MO is a huge benefit in itself, as the latter is an excellent source of vitamins, potassium among other nutrients.

\section{CONCLUSIONS}

1- MO extract has an effective anti-carcinogenic role in the treatment of squamous cell carcinoma

2- CisPt $50 \mathrm{mg}$ is more effective in the treatment of cancer than CisPt $20 \mathrm{mg}$

3- The combined use of both $\mathrm{MO}$ and $\mathrm{CisPt}$ is more effective in the treatment of squamous cell carcinoma, than the use of either of them separately, in a dose and duration dependant manner.

4- MO can be used combined with CisPt 20 $\mathrm{mg}$ for $48 \mathrm{hrs}$ to achieve similar effectiveness but fewer side effects than when using CisPt $50 \mathrm{mg}$ for the same duration. 


\section{RECOMMENDATIONS}

MO is a health friendly plant that should be consumed on a daily basis in our diet

\section{REFERENCES}

1- Stohs S \& Hartman M (2015): Review of the Safety and Efficacy of Moringa oleifera. phytotherapy research; 29: 796-804

2- Leone A, Spada A, Battezzati A, Schiraldi A, Aristil J \& Bertoli S (2015); Cultivation, genetic, ethnopharmacology, phytochemistry and pharmacology of Moringa oleifera leaves: an overview. Int J Mol Sci. 16 (6): 12791-835.

3- Atawodi S, Atawodi J, Idakwo G, Pfundstein B, Haubner R, Wurtele G, Bartsch H \& Owen R. (2010); Evaluation of the polyphenol content and antioxidant properties of methanol extracts of the leaves, stem, and root barks of Moringa oleifera Lam. Journal of Medicinal Food. 13: 710-716.

4- Vongsak B, Sithisarn $\mathrm{P}$ \& Gritsanapan W (2014):Simultaneous HPLC Quantitative Analysis of Active Compounds in Leaves of Moringa oleifera Lam.. J Chromatogr Sci ; 52 : 641-645.

5- Gopalakrishnan L, Doriya K \& Kumar D (2016): Moringaoleifera: A review on nutritive importance and its medicinal application. Food Science and Human Wellness; $5,49-56$.

6- Fiorinia C, Cordania M, Gottea G, Piconeb D \& Donadelli M (2015): Onconase induces autophagy sensitizing pancreatic cancer cells to gemcitabine and activates Akt/ mTOR pathway in a ROS-dependent manner; BBA molecular cell research. 1853: 549-560.

7- Kroemer G (2006): Mitochondria in cancer. Oncogene; $25,4630-4632$.

8- Ivanova D, Zhelev Z, Aoki I, Bakalova R, and Higashi $\mathrm{T}$ (2016): Overproduction of reactive oxygen species obligatory or not for induction of apoptosis by anticancer drugs. Chin J Cancer Res; 28: 383-396.

9- Boonstra J \& Post J (2004): Molecular events associated with reactive oxygen species and cell cycle progression in mammalian cells. Gene; 4: 1-13.

10- Saini R, Sivanesan I \& Keum Y (2016): Phytochemicals of Moringaoleifera: a review of their nutritional, therapeutic and industrial significance. Biotech. 6: 203-204
11- Kalkunte S, Swamy N, Dizon D \& Brard L (2006): Benzyl isothiocyanate (BITC) induces apoptosis in ovarian cancer cells in vitro. J ExpTherOncol.;5: 287-300.

12- Bishayee K, Ghosh S, Mukherjee A, Sadhukhan R, Mondal J, Khuda-Bukhsh AR (2013): Quercetin induces cytochrome c release and ROS accumulation to promote apoptosis and arrest the cell cycle in G2/M, in cervical carcinoma: signal cascade and drug-DNA interaction. Cell Prolif.;46 (2):153-163.

13- Siddik Z (2003): Cisplatin: mode of cytotoxic action and molecular basis of resistance. Oncogene; 22: 7265-7279.

14- Levina E, Oren M \& Ben-Ze'ev A (2004): Downregulation of beta-catenin by $\mathrm{p} 53$ involves changes in the rate of betacatenin phosphorylation and Axin dynamics. Oncogene; 23:4444-4453.

15- Marullo R, Werner E, Degtyareva N, Moore B, Altavilla G, Ramalingam S, et al. (2013): Cisplatin induces a mitochondrial-ROS response that contributes to cytotoxicity depending on mitochondrial redox status and bioenergetic functions; .PLoS ONE 8 (11): e81162.

16- Hess J \& Khasawneh M (2015): Cancer metabolism and oxidative stress: Insights into carcinogenesis and chemotherapy via the non-dihydrofolate reductase effects of methotrexate. BBA clinical; 3: 152-161.

17- Dasari S \& Tchounwou P (2014): Cisplatin in cancer therapy: molecular mechanisms of action. Eur J Pharmacol.; 740: 364-378.

18- Shen D, Pouliot L, Hall M \& Gottesman M (2012): Cisplatin Resistance: A Cellular Self-Defense Mechanism Resulting from Multiple Epigenetic and Genetic Changes. Pharmacol Rev.; 64: 706-721.

19- Claerhout S, Verschooten L, Kelst S, De Vos R, Proby C, Agostinis P \& Garmyn M (2010): Concomitant inhibition of AKT and autophagy is required for efficient cisplatininduced apoptosis of metastatic skin carcinoma. IJC; 127: 2790-2803.

20- Zhang J, Zhang L, Shen L, Xu X \& Gang H (2013): Regulation of AKT gene expression by cisplatin. OncolLett.; 5: 756-760.

21- Koole K, Clausen M, van Es R, van Kempen P, Melchers L, Koole R, Langendijk J, van Diest P, Roodenburg J, Schuuring E \& Willems S ( 2016): FGFR Family Members Protein Expression as Prognostic Markers in Oral Cavity and Oropharyngeal Squamous Cell Carcinoma; Mol Diagn Ther; 20: 363-374. 
22- Hanahan D \& Weinberg R (2011): Hallmarks of cancer: the next generation. $144 ; 646-674$.

23- Rokudai S, Fujita N, Hashimoto Y \& Tsuruo T (2000): Cleavage and inactivation of antiapoptotic AKT/PKB by caspases during apoptosis. J Cell Physiol.;182:290-296.

24- Chen H, Liang Z, Wang Z, Zhang J, Hu B, Xing X, Cai W (2015): akt activation and inhibition of cytochrome c release: mechanistic insights into leptin-promoted survival of type ii alveolar epithelial cells. J Cell Biochem.;116 : 2313-2324

25- Zhou H, Li X, Meinkoth J \& Pittman R (2000): AKT regulates cell survival and apoptosis at a post mitochondrial level. The journal of cell biology; 151:483-494.

26- Fang D, Hawke D, Zheng Y, Xia Y, Meisenhelder J, Nika H, Mills G, Kobayashi R, Hunter T \& Lu Z (2007): Phosphorylation of $\beta$-Catenin by AKT promotes $\beta$-catenin transcriptional activity. The journal of biological chemistry; 282: 11221-11229.

27- Geyer F, Lacroix-Triki M, Savage K, Arnedos M, Lambros M, MacKay A, Natrajan R \& Reis-Filho J (2011): $\beta$-Catenin pathway activation in breast cancer is associated with triple-negative phenotype but not with CTNNB1 mutation. Modern Pathology; 24: 209-231.

28- Yun X, Wang L, Cao L, Okada N \& Miki Y (2010): Immunohistochemical study of $\beta$-catenin and functionally related molecular markers in tongue squamous cell carcinoma and its correlation with cellular proliferation. OncolLett; 1: 437-443.

29- MacDonald B, Tamai K \& He X (2009): Wnt/ß-catenin signaling: components, mechanisms, and diseases. Dev Cell.; 17: 9-26.

30- Brembeck F, Schwarz-Romond T, Bakkers J, Wilhelm S, Hammerschmidt M \& Birchmeier W. (2004): Essential role of BCL9-2 in the switch between beta-catenin's adhesive and transcriptional functions. Genes Dev.; 18: 2225-2230.

31- Clevers H (2006): Wnt/beta-catenin signaling in development and disease. Cell. ;127:469-480.

32- Xu W, Kimelman D ( 2007): Mechanistic insights from structural studies of beta-catenin and its binding partners. J Cell Sci.;1: 3337-3344.

33- Abe K \& Takeichi M (2007): NMDA-receptor activation induces calpain-mediated $\beta$-catenin cleavages for triggering gene expression. neuron; 53: 387-397
34- Olmeda D, Castel S, Vilaró S \& Cano A (2003): $\beta$-Catenin Regulation during the Cell Cycle: Implications in G2/M and Apoptosis. MolBiol Cell. ; 14: 2844-2860.

35- Nowsheen S \& Yang E (2012): The intersection between DNA damage response and cell death pathways. ExpOncol.; 34: 243-254.

36- Olsson M \& Zhivotovsky B (2011): Caspases and cancer. Cell Death Differ.; 18: 1441-1449.

37- Cain K, Bratton S \& Cohen G (2002): The Apaf-1 apoptosome: a large caspase-activatingcomplex. Biochimie; 84 :203-214.

38- Elmore S (2007): Apoptosis: a review of programmed cell death. Toxicolpathol.; 35: 495-516.

39- Kuwahara D, Tsutsumi K, Kobayashi T, Hyoudou M, Koizuka I (2002): [Inhibition of caspase-9 activity in cisplatin-resistant head and neck squamous cell carcinoma. Nihon Jibiinkoka Gakkai Kaiho.;105:152-157.

40- Pfaffl M (2001): A new mathematical model for relative quantification in real-time RT-PCR. Nucleic Acids Res; 29: e45 .

41- El-Kareh A (2003): A Mathematical Model for Cisplatin Cellular Pharmacodynamics. Neoplasia; 5: 161-169

42- Florea A \& Büsselberg D (2011): Cisplatin as an AntiTumor Drug: Cellular Mechanisms of Activity, Drug Resistance and Induced Side Effects. Cancers; 3: 351-1371.

43- Andriani F, Perego P, Carenini N, Sozzi G \& Roz L (2006): Increased sensitivity to cisplatin in non-small cell lung cancer cell lines after FHIT gene transfer. Neoplasia.; 8:9-17.

44- Bae-Jump V., Zhou, C., Boggess, J \& Gehrig P (2009); Synergistic effect of rapamycin and cisplatin in endometrial cancer cells. Cancer, 115: 3887-3896.

45- Traynor A, Richards G, Hartig G, Khuntia D, Cleary J,Wiederholt P, Bentzen S \& Harari P (2010): Comprehensive IMRT plus weekly cisplatin for advanced head and neck cancer. the university of wisconsin experience head neck; 32: 599-606.

46- Wu J, Ryan T, Levinson B, Newman E, Hochster H \& Muggia $\mathrm{F}$ (2012): Cisplatin with capecitabine: tolerance and activity in a phase $\mathrm{i} / \mathrm{ii}$ study preferentially enrolling patients with gastric cancer. Anticancer Research; 32: 939-945.

47- Astolfi L, Ghiselli S, Guaran V, Chicca M, Simoni E, Olivetto E, Lelli G \& Martini A (2013): Correlation of adverse effects of cisplatin administration in patients affected by solid tumours: A retrospective evaluation. Oncol Rep.; 29: 1285-1292. 
48- Sangawa A, Shintani M, Yamao N \& Kamoshida S (2014): Phosphorylation status of AKT and caspase-9 in gastric and colorectal carcinomas. Int J ClinExpPathol.; 7: 33123317.

49- Maseki S, Ijichi K, Tanaka H, Fujii M, Hasegawa Y, Ogawa T, Murakami S, Kondo E \& Nakanishi H (2012): Acquisition of EMT phenotype in the gefitinib-resistant cells of a head and neck squamous cell carcinoma cell line through Akt/GSK-3 $\beta /$ snail signalling pathway. Br J Cancer.; 106: 1196-1204.

50- Batra P \& Sharma A (2013): Anti-cancer potential of flavonoids: recent trends and future perspectives. 3 Biotech.; 3: 439-459.

51- Gysin R, Azzi A \& Visarius T (2002): Gamma-tocopherol inhibits human cancer cell cycle progression and cell proliferation by down-regulation of cyclins. FASEB J.;16:1952-1954.

52- Amado N, Fonseca B, Cerqueira D, Neto V, Abreu J (2011): Flavonoids: Potential Wnt/beta-catenin signaling modulators in cancer. Life Sciences; 89 : 545-554

53- Chandele A, Prasad V, Jagtap J, Shukla R \& Shastry $P$ (2004): Upregulation of survivin in $G 2 / M$ cells and inhibition of caspase 9 activity enhances resistance in staurosporine-induced apoptosis. Neoplasia; 6: 29 - 40.

54- Campbell S, Stone W, Whaley S, Qui M \& Krishnan K (2003): Gamma $(\gamma)$ tocopherol upregulates peroxisome proliferator activated receptor (PPAR) gamma $(\gamma)$ expression in SW 480 human colon cancer cell lines. BMC Cancer. 3:25-26.
55- Yu W, Yiqing Y, Yiqing Li, Jia L, Park S, Li J, Gopalan A, Menchaca M, Sanders B \& Kline K (2009): Anticancer actions of natural and synthetic vitamin $\mathrm{E}$ forms: RRR- $\alpha$ tocopherol blocks the anticancer actions of $\gamma$-tocopherol. MolNutr Food Res.; 53: 1573-1581.

56- Niu G, Yin S, Xie S, Li Y, Nie D, Ma L, Wang X, WuY(2011): Quercetin induces apoptosis by activating caspase-3 and regulating Bcl-2 and cyclooxygenase-2 pathways in human HL-60 cells. Acta Biochim Biophys Sin (Shanghai); 43: 30-37

57- Karim N, Ibrahim M, Kntayya S, Rukayadi Y, Abd Hamid H \& Abdull Razis A (2016): Moringa oleifera Lam: targeting chemoprevention. Asian Pac J Cancer Prev.; 17, 3675-3686.

58- Kuwahara D, Tsutsumi K, Kobayashi T, Hasunuma T \& Nishioka K (2000): Caspase-9 regulates cisplatininduced apoptosis in human head and neck squamous cell carcinoma cells. Cancer Lett.;148:65-71.

59- Omori E, Matsumoto K \& Tsuji J (2011): Non-canonical $\beta$-catenin degradation mediates reactive oxygen speciesinduced epidermal cell death. Oncogene; 30: 3336-3344.

60- Liberti M \& Locasale J(2016): The warburg effect: how does it benefit cancer cells?. Trends Biochem Sci.; 41: 211-218.

61- Navarro L, Li F \& Lampe J (2011): Mechanisms of action of isothiocyanates in cancer chemoprevention: an update. Food Funct.; 14; 2: 579-587.

62- Sethi D, Sen R, Parshad S, Khetarpal S, Garg M \& Sen J (2012): Histopathologic changes following neoadjuvant chemotherapy in various malignancies. International journal of applied basic medical research.; 2: 111-116. 